\title{
RAPID BIOASSAY FOR EVALUATING ENZYME PRODUCTION IN FUNGAL ISOLATES FROM ENVIRONMENTAL SOURCES
}

ELEONORA BORDO, FRANCESCA LUZIATELLI, SILVIA CROGNALE, SARA MARINARI, STEFANO GREGO, MAURIZIO RUZZI

"Department of Agrobiology and Agrochemistry, University of Tuscia, , Via San Camillo de Lellis, s.n.c., Viterbo, Italy

\section{Introduction}

Fungal hydrolytic enzymes have a great potential due to the rapid development of enzyme technology and their industrial applications. To screen hydrolase-producing microbial strains the fluorimetric method could constitute an effective alternative to the spectrophotometric method. In fact the substrates used are conjugates of the highly fluorescent compounds 4-methylumbelliferone (MUB) and thus product formation can be measured directly in the microplate without previous extraction and purification of the product.

\section{Objective}

The objective of this work was to develop a rapid method for measuring activity of $\beta$-D-exoglucanase, $\beta$-D-glucosidase, $\alpha$-Dglucosidase, $\beta-\mathrm{N}$-acetyl-exosaminidase and $\beta$-D-xylosidase in culture broth samples of nine fungal strains isolated from shrub species (Tamarix) that can be used in phytoremediation.

\section{Microplate Fluorimetric Enzymatic Assay}

Enzymatic activities were measured using microplate fluorimetric enzymatic assays on culture filtrates periodically collected from the broths. Five enzyme substrates based on 4methylumbelliferone (MU) were used for the detection of five extracellular hydrolytic enzymatic activity. The substrates were dissolved in 20 ul of dimethyl sulfoxide and diluted in sodium acetate trihydrate $0.5 \mathrm{M} \mathrm{pH} 5.5$. The resulting working solutions of 10 $\mu \mathrm{M}$ were kept at $4 \mathrm{C}$. Each well of the microplate contained: substrate solution, $100 \mu \mathrm{l}$; an appropriate dilution of culture filtrate, 20 ul sodium acetate trihydrate $0.5 \mathrm{M} \mathrm{pH} 5.5$ to $250 \quad \mu l$. Standard curves construction, fluorescence readings and processing data were obtained as described from Marx et al. 2001.

\section{Culture maintanance and enzyme production}

Isolates were maintained on a potato-dextrose agar at $30 \mathrm{C}$, while two liquid media, named (1) and (2), containing Avicell PH 101 as inducer were used for enzymatic production. After inoculum cultures were incubated at $30 \mathrm{C}$ in a rotary shaker at 180 rpm.

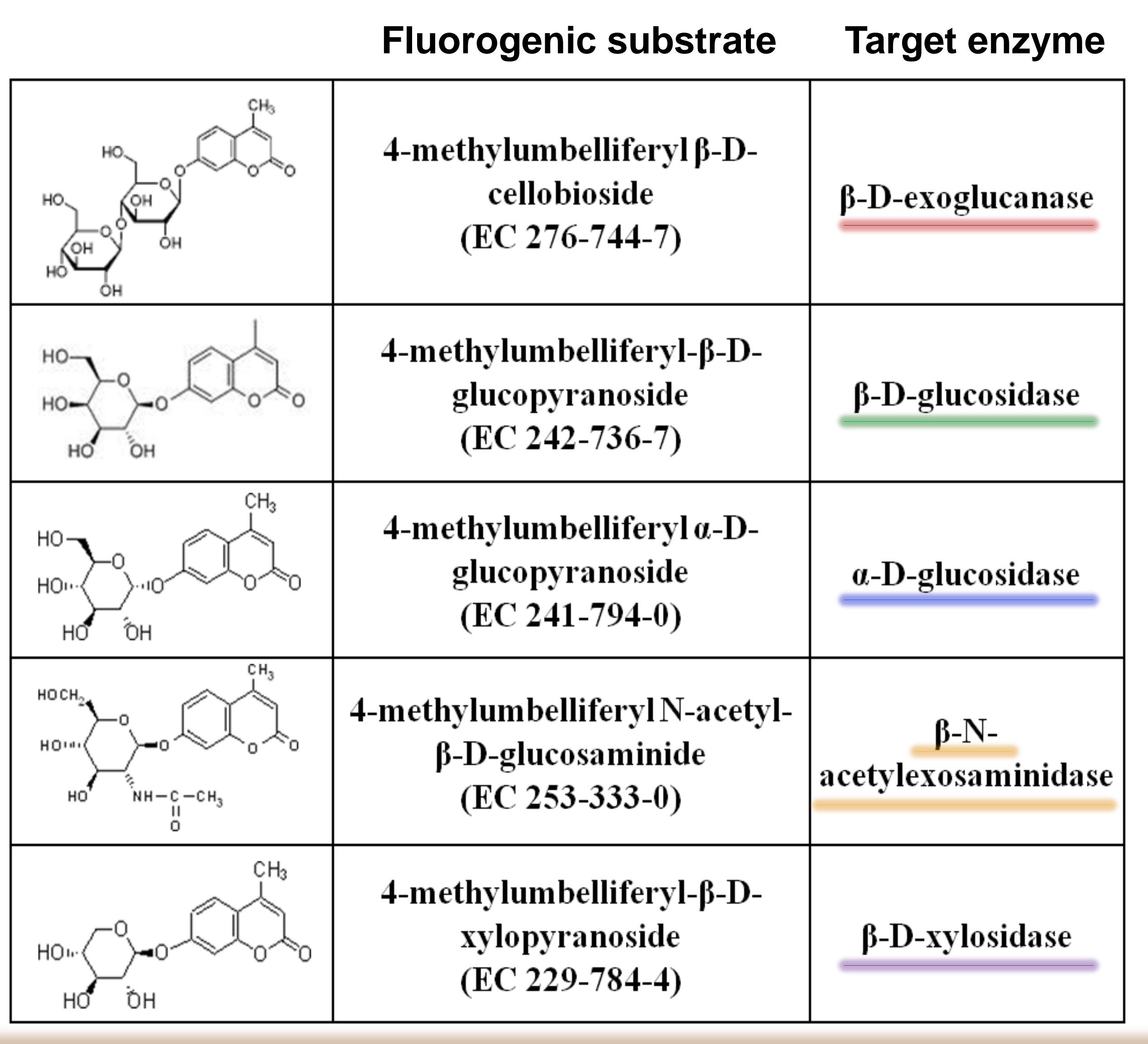

\section{Substrate saturation curves}

For the choice of the appropriate dilution of culture filtrates were constructed substrate saturation curves using a commercial cellulase purified from Aspergillus niger. Six serial dilutions was obtained from a solution containing $2 \mathrm{mg}$ of the enzyme dissolved in $10 \mathrm{ml}$ of sterile water. The dilutions were analyzed through microplate fluorimetric assay as described on the left.
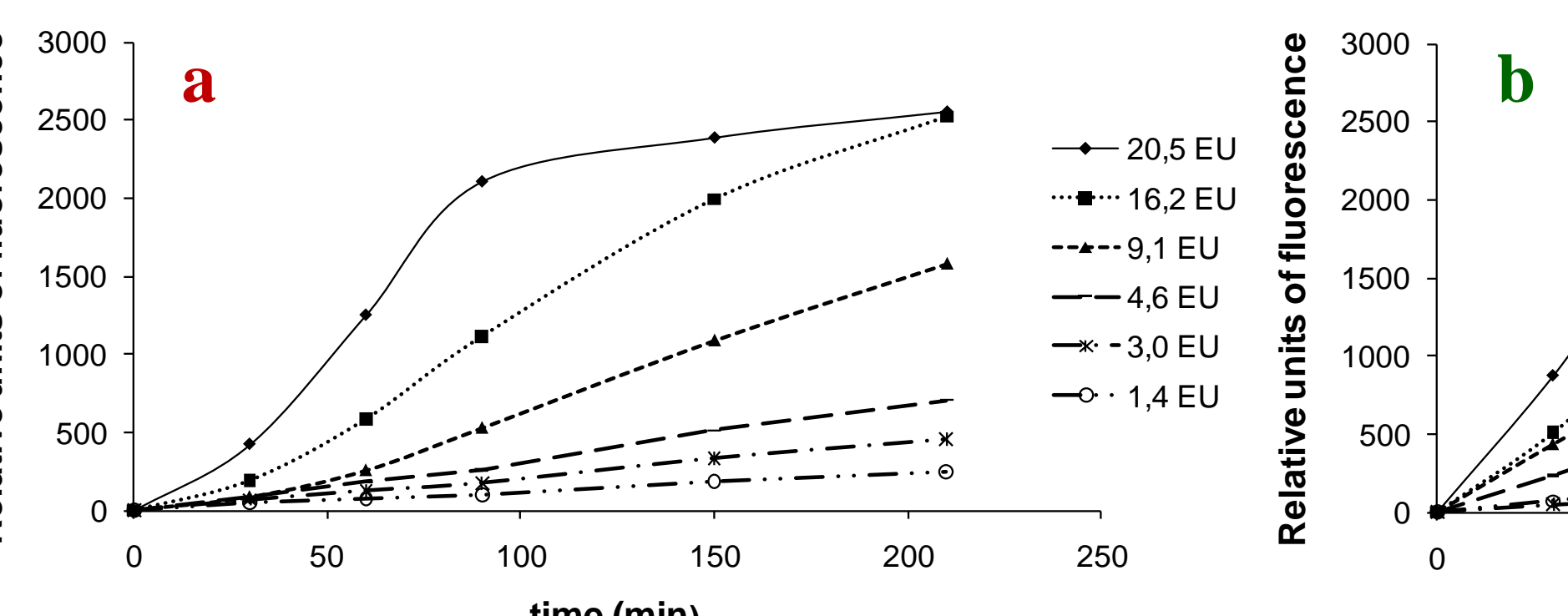

Fig. 1 Substrate saturation curves for $\beta$-D-exoglucanasic (a) and $\beta$-D-glucosidasic (b) activity in solutions with different enzymatic activity obtained using a commercial cellulase purified from Aspergillus niger. EU= Enzymatic Units ( $\mu \mathrm{mol} \mathrm{ml}-1 \mathrm{~min}-1$ )

Results shown that enzymatic activities higher than 20 EU cause substrate saturation and so must be diluted to be precisely detected from the instrument (Fig.1).

\section{Enzymatic activities in medium (1)}

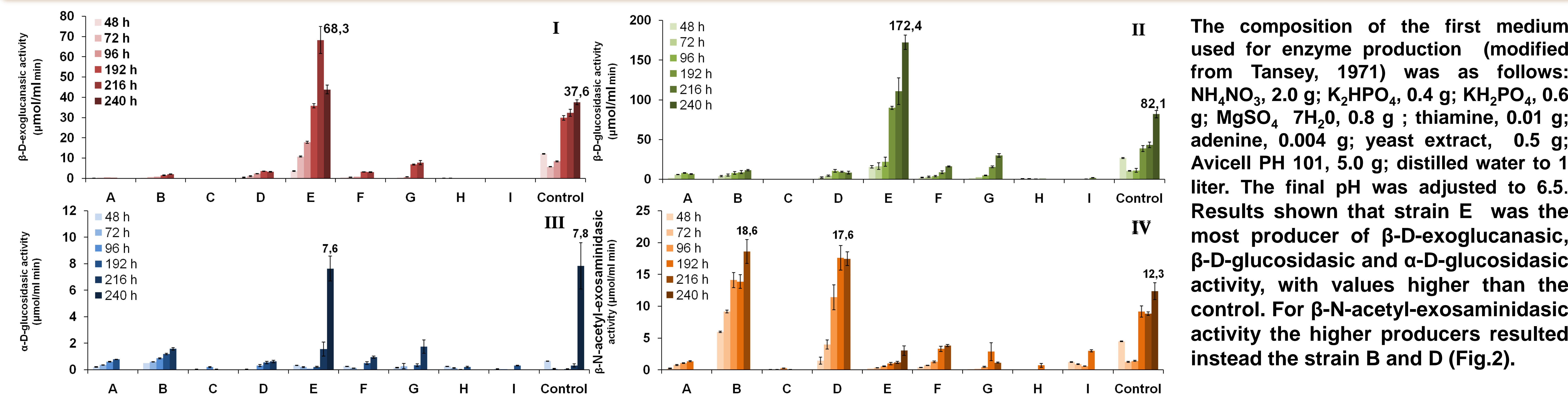

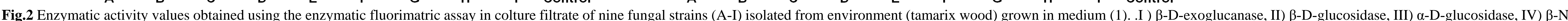
acetyl-exosaminidase (A-I) Control: Trichoderma viride; h: hours from inoculum (values reported are the average S.D. of the values obtained in six different experiments)

\section{Enzymatic activities in medium (2)}

The second medium (modified from Olama and Sabry, 1989) was used to further characterize the strain E, resulted the most interesting in previous analysis.

The composition of the medium was as follows: $\mathrm{NaNO}_{3}, 3.0 \mathrm{~g} ; \mathrm{KCl}$, $0.5 \mathrm{~g} ; \mathrm{K}_{2} \mathrm{HPO}_{4}, 1.0 \mathrm{~g} ; \mathrm{MgSO}_{4} 7 \mathrm{H}_{2} \mathrm{O}$, $0.5 \mathrm{~g} ; \mathrm{Fe} \mathrm{SO}_{4}, 0.01 \mathrm{~g} ; \mathrm{CaCl}_{2}, 1.0 \mathrm{~g}$ yeast extract, $5.0 \mathrm{~g}$; Avicell $\mathrm{PH} 101$, $25.0 \mathrm{~g}$; distilled water to 1 liter. The final $\mathrm{pH}$ was adjusted to 7.0. Medium (2) resulted more adapted for enzyme production by strain $\mathrm{E}$ since all its enzymatic activities were higher respect to the control and respect to the same strain grown on medium (1) (Fig.3).

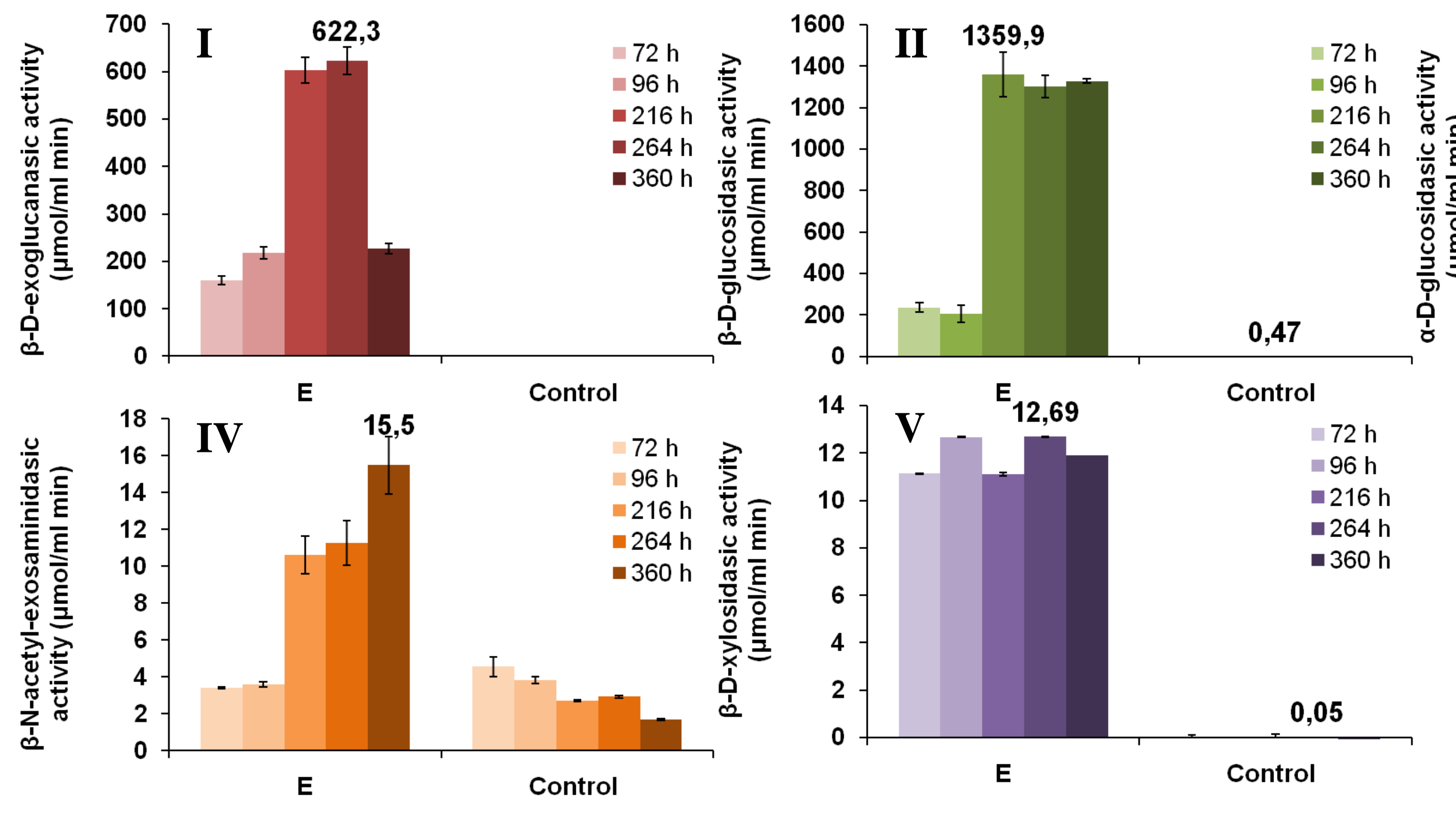

\section{CONCLUSIONS}

The microplate fluorimetric enzymatic assay constitutes a rapid and sensitive method for evaluating enzyme production in fungal isolates. Its use allowed to select a fungal strain able to produce high levels of five specific hydrolases respect to the control Trichoderma viride. The selected strain is potentially interesting for industrial applications. 